\title{
NOTE
}

\section{Virus-like particles associated with mortalities of the carpet-shell clam Ruditapes decussatus}

\author{
B. Novoa, A. Figueras* \\ Instituto de Investigaciones Marinas, CSIC, Eduardo Cabello 6, 36208 Vigo, Spain
}

\begin{abstract}
During the late summer and early fall of 1997 and 1998 heavy mortalities were detected in the carpet-shell clam Ruditapes decussatus cultured in Galicia (NW Spain). The prevalences and intensities of the parasites found in the histopathological studies were not high enough to explain the high mortality rates. Unenveloped virus-like particles were detected by transmission electron microscopy in the cytoplasm of the connective tissue cells. They had an icosahedrical-spherical shape with a diameter of 27 to $35 \mathrm{~nm}$. These virus-like particles appeared free in the cytoplasm or associated with endoplasmic reticulum membranes. These characteristics suggest that they belong to the Picornaviridae family.
\end{abstract}

KEY WORDS: Clam - Ruditapes decussatus - Picomavirus-like

Clam Ruditapes deccussatus culture has a relatively high economic value in Galicia (NW of Spain). The annual production is stable around 2000 metric $t$ with a value of 1500 pesetas (US\$ 10) per kilogram. Two pathological agents, Vibrio tapetis and Perkinsus atlanticus, have previously been identified as the main cause of mortalities of carpet-shell clams in this area. Brown ring disease (BRD) has been associated with mass mortalities of Manila clams $R$. philippinarum in France and Spain, causing important economical losses (Paillard et al. 1989, Castro et al. 1990, 1992, Figueras et al. 1996). The carpet-shell clam is also affected by BRD (Figueras et al. 1996). The characteristic signs are the appearance of brown conchioline deposits of variable distribution and thickness on the inner shell of diseased clams. Paillard et al. (1994) and Paillard \& Maes (1994) have established that a strain of Vibrio is the etiological agent of BRD for clams and, recently, Borrego et al. (1996) named it $V$. tapetis based on

• Corresponding author. E-mail: pato1@iim.csic.es phenotypical and molecular biology characteristics. $P$. atlanticus was first described by Azevedo (1989) and Azevedo et al. (1990) as a parasite causing mortalities of the carpet-shell clam $R$. decussatus on the southern coast of Portugal. The presence of a Perkinsus-like organism was associated with heavy mortalities among carpet shells in Spain by Figueras et al. (1992). Subsequently Perkinsus was detected in other localities along the Galician coast (NW of Spain) not only in the carpet-shell clam $R$. decussatus but also in the Manila clam R. philippinarum (Figueras et al. 1996),

Few clam diseases associated with viruses have been described, the most significant being several birnaviruses isolated from Meretrix lusoria cultured in Taiwan (Lo et al. 1988).

During the late summer and early autumn of 1997 and 1998 heavy mortalities were detected in carpetshell clam Ruditapes decussatus cultured in 2 areas of the Galician coast (NW Spain). In this work, we present the results of our investigation over the cause of these abnormal mortalities.

Material and methods. Clams: Two batches of clams from cultured populations suffering mortalities were taken to the laboratory, maintained in a closed circuit aquarium system at $15^{\circ} \mathrm{C}$ and $35 \%$ salinity with constant aeration and fed daily with Tetraselmis svecica.

Histopathological studies: Clams were fixed whole after removing the shell in Davidson's fixative for $24 \mathrm{~h}$, and oblique transverse sections approximately $5 \mathrm{~mm}$ thick were taken from each specimen so that mantle, gonad, digestive gland gills, kidney and foot tissue were included. Tissue samples were embedded in paraffin and $5 \mu \mathrm{m}$ sections were stained with haematoxylin-eosin. Clam histological sections were examined for the presence of parasites with the aid of a microscope at 400 to $1000 \times$ magnification (Nikon).

Diagnosis of Perkinsus atlanticus using Ray's thioglycollate fluid medium (RTFM): In order to determine 

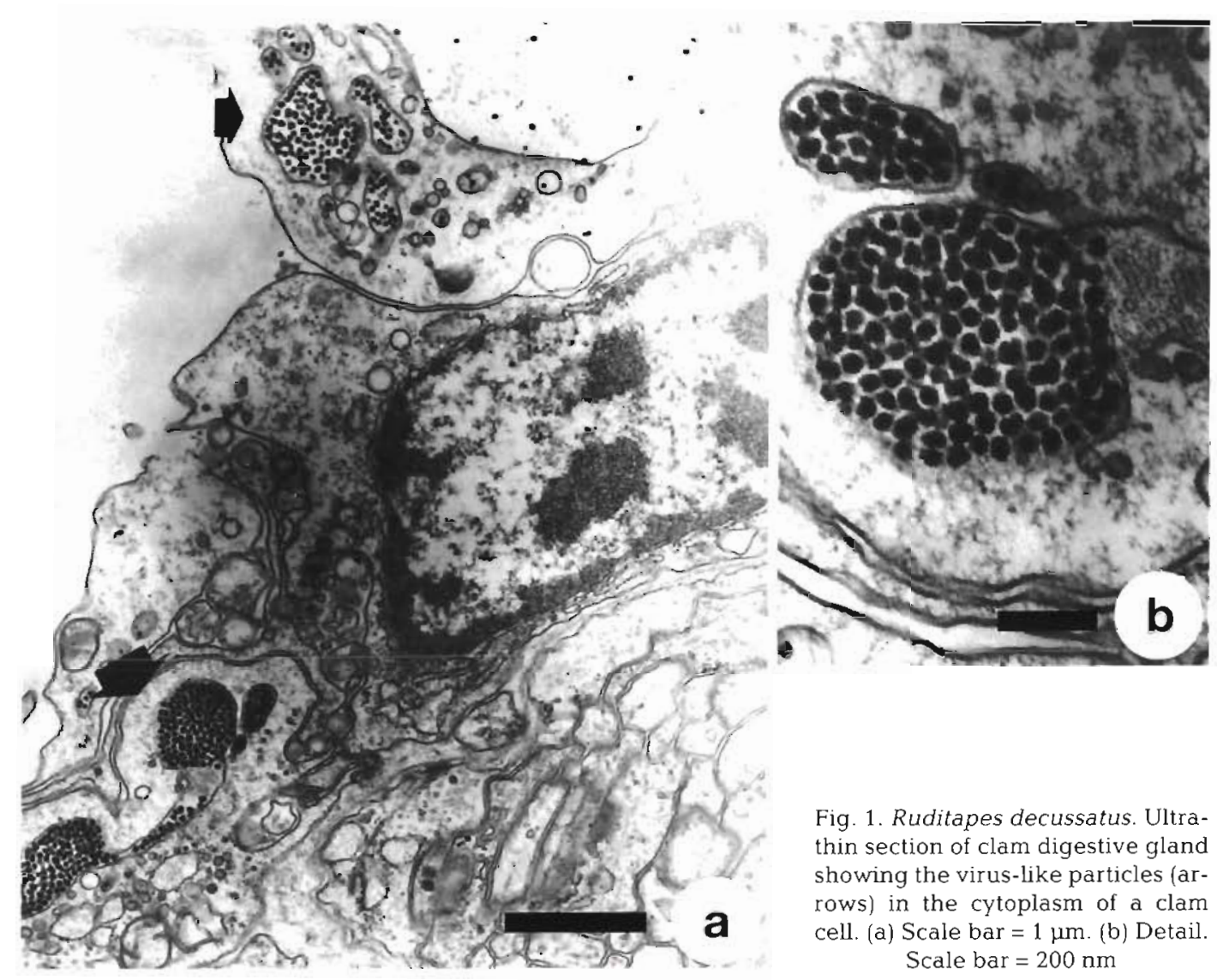

Fig. 1. Ruditapes decussatus. Ultrathin section of clam digestive gland showing the virus-like particles (arrows) in the cytoplasm of a clam cell. (a) Scale bar $=1 \mu \mathrm{m}$. (b) Detail. Scale bar $=200 \mathrm{~nm}$

if the clam mortalities were associated with the infection by Perkinsus atlanticus, gills of gaping clams were placed in RTFM (Ray 1954). Nystatin was added prior to introducing the tissue to reduce fungal contamination. After $3 \mathrm{~d}$ of incubation in the dark at room temperature, gills were placed on a slide, stained with Lugol's iodine and observed with a light microscope

Transmission electron microscopy: Small pieces of clam tissue (digestive gland) were processed for transmission electron microscopy. Tissues were fixed in cold, $0.1 \mathrm{M}$ sodium cacodylate buffered $2 \%$ osmium tetroxide for $1 \mathrm{~h}$, washed, dehydrated in an ascending graded series of alcohol, followed by two $10 \mathrm{~min}$ changes in propylene oxide, and embedded in EponAraldite. Ultrathin sections were cut using an Ultracut S Reichert Jung Ultramicrotome and stained using lead citrate and uranyl acetate. Ultrathin sections were examined using a Phillips CM 100 TEM.

Results and discussion. Two batches of clams from populations in which growers claimed a high mortality rate were maintained in the laboratory aquarium facilities. These clams showed a cumulative mortality of $97.8 \%$ in a month. In contrast, other stocks of clams, brought at the same time from different Galician areas and maintained in the same conditions, showed mortality of less than $20 \%$. All of the clams examined for
Perkinsus atlanticus using the RTFM technique were negative for the presence of this parasite. Histological studies showed the presence of several species of protozoan parasites (a haplosporidian, probably Haplosporidium tapetis, and an unidentified coccidian) but with low prevalences and intensities that lead us to rule them out as the possible cause of the high mortality rate.

Ultrastructurally, virus-like particles were observed in the cytoplasm of connective tissue cells (Fig. 1). They appeared free in the cytoplasm or associated with endoplasmic reticulum membranes and cytoplamic vesicles. The virus-like particles were icosahedrical-spherical in shape, 27 to $35 \mathrm{~nm}$ in diameter and did not possess an envelope. Nuclei of infected cells were enlarged with dispersed chromatin which sometimes was condensed near the nuclear membrane. The cytoplasmic content of these cells was reduced compared with uninfected cells

The size, morphology and the replication in the cytoplasm in association with the endoplasmic reticulum and with cytoplasmic vesicles of these viral particles suggest that they belong to the Picornaviridae family (Yilma \& Breese 1980). Our findings resembled those described for the bovine enterovirus replication by Yilma \& Breese (1980). 
To our knowledge, this is the first description of a putative virus in carpet-shell clams. Similar viruses have been associated previously with bivalve molluscs mortalities in New Zealand (Jones et al. 1996, Hine $\&$ Wesney 1997) and with granulocytomas in blue mussels (Rasmussen 1986)

The significance of these findings is still unknown. More research is being carried out in order to further characterize the virus and to determine the influence of environmental factors on the development of the disease. Experimental infections by cohabitation and by injection of an homogenate of tissues from moribund clams are being carried out to confirm the role of these virus-like particles as the cause of these mortalities

Acknowledgements. The authors wish to thank Dr P. M. Hine for his comments on the ultrastructural identification of the virus. We also want to thank C. Beloso, A. Simón and J. R. Caldas for their cooperation.

\section{LITERATURE CITED}

Azevedo C (1989) Fine structure of Perkinsus atlanticus n. sp. (Apicomplexa, Perkinsea) parasite of the clam Ruditapes decussatus from Portugal. J Parasitol 75:627-635

Azevedo C, Corral L, Cachola R (1990) Fine structure of zoosporulation in Perkinsus atlanticus (Apicomplexa, Perkinsea). Parasitology 100:351-358

Borrego JJ, Luque A, Castro D, Santamaría JA, MartínezManzanares E (1996) Virulence factors of Vibrio P1, the causative agent of brown ring disease. Aquat Liv Res 9: $125-136$

Castro D, Monnigo MA, Martínez E, Cornax E, Borrego JJ (1990) Microflora associated with 'brown ring' from clams (Tapes semidecussatus) cultured in southwestern Spain.

Editorial responsibility: Albert Sparks,

Seattle, Washington, USA
In: Figueras A (ed) Abstracts 4th Int Coll Pathol Mar Aquac September 1990, Vigo, p 56

Castro D, Martínez-Manzanares E, Luque A, Fouz B, Morin̄igo MA, Borrego JJ, Toranzo AE (1992) Characterization of strains related to brown ring disease outbreaks in southwestern Spain. Dis Aquat Org 14:229-236

Figueras A, Robledo JAF, Novoa B (1992) Occurrence of haplosporidian and Perkinsus-like infections in carpetshell clams, Ruditapes decussatus (Linnaeus, 1758), of the Ría de Vigo (Galicia, NW Spain). J Shellfish Res 11: $377-382$

Figueras A, Robledo JAF, Novoa B (1996) Brown ring disease in clams (Ruditapes decussatus and $R$. philippinarum) from Spain and Portugal. J Shellfish Res 15:363-368

Hine PM, Wesney B (1997) Virus-like particles associated with cytopathology in the digestive gland epithelium of scallops Pecten novaezelandiae and toheroa Paphies ventriculosum. Dis Aquat Org 29:197-204

Jones JB, Scotti PD, Dearing SC, Wesney B (1996) Virus-like particles associated with marine mussel mortalities in New Zealand. Dis Aquat Org 25:143-149

Lo CF, Hong YW, Huang SY, Wang CH (1988) The characteristics of the virus isolated from the gill of clam, Meretrix lusoria. Fish Pathol 23:147-154

Paillard C. Maes P (1994) The brown ring disease symptom in the manila clam, Ruditapes philippinarum: establishment of a classification system. Dis Aquat Org 19:137-146

Paillard C, Percelay L, Le Pennec M, Picard D (1989) Origine pathogène de 'l'anneau bru' chez Tapes philippinarum (Mollusque, bivalve). C R Acad Sci Sér III 309:235-241

Paillard C, Maes P, Oubella R (1994) Brown ring disease in clams. Annu Rev Fish Dis 4:219-240

Rasmussen LPD (1986) Virus-associated granulocytomas in the marine mussel, Mytilus edulis, from three sites in Danemark. J Invertebr Pathol 48:117-123

Ray SM (1954) Biological studies of Dermocystidium marinum. Rice Institute Pamphlet, Special Issue. The Rice Institute, Houston, TX

Yilma T, Breese SS (1980) Morphogenesis of the assembly and release of bovine enterovirus. J Gen Virol 49:225-230

Submitted: January 6, 1999; Accepted: September 8, 1999

Proofs received from author(s): December 16, 1999 